Chapman University

Chapman University Digital Commons

Food Science (MS) Theses

Dissertations and Theses

Spring 5-22-2019

\title{
Use of Gamma Irradiation as an Intervention Treatment to Inactivate Escherichia coli 0157:H7 in Freshly Extracted Apple Juice
}

Dielle Aurelia Fernandes

Chapman University, ferna201@mail.chapman.edu

Follow this and additional works at: https://digitalcommons.chapman.edu/food_science_theses

Part of the Food Microbiology Commons

\section{Recommended Citation}

Fernandes, D. A. (2019). Use of gamma irradiation as an intervention treatment to inactivate Escherichia coli 0157:H7 in freshly extracted apple juice. Master's thesis, Chapman University. https://doi.org/ 10.36837/chapman.000069

This Thesis is brought to you for free and open access by the Dissertations and Theses at Chapman University Digital Commons. It has been accepted for inclusion in Food Science (MS) Theses by an authorized administrator of Chapman University Digital Commons. For more information, please contact laughtin@chapman.edu. 
Use of Gamma Irradiation as an Intervention Treatment to Inactivate Escherichia coli O157:H7 in Freshly Extracted Apple Juice

A Thesis by

Dielle Aurelia Fernandes

Chapman University

Orange, CA

Schmid College of Science and Technology

Submitted in partial fulfillment of the requirements for the degree of

Master of Science in Food Science

May 2019

Committee in charge:

Anuradha Prakash, Ph.D., Chair

Donna M. Williams-Hill, Ph.D.

Denise Foley, Ph.D.

Kirsten Hirneisen, Ph.D. 
The thesis of Dielle Aurelia Fernandes is approved.

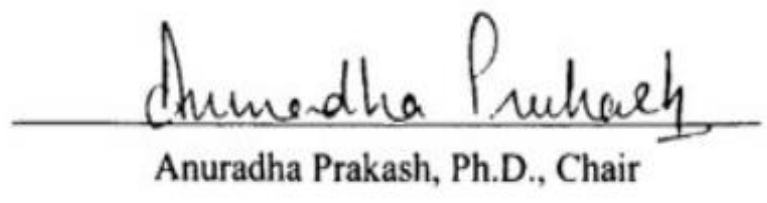

Doxam wellemin xted Donna M. Williams-Hill, Ph.D.
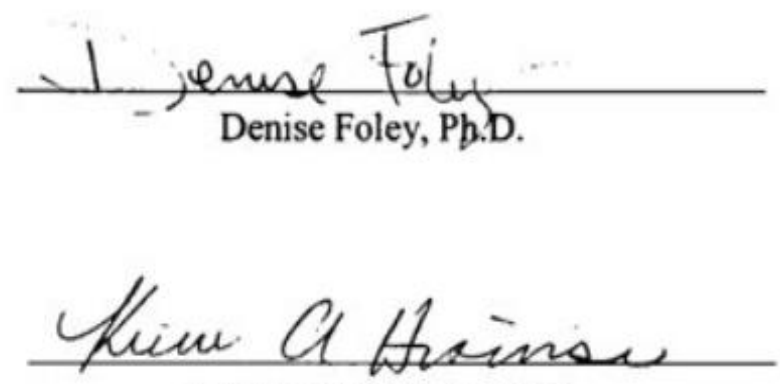

Kirsten Hirneisen, Ph.D.

May 2019 
Use of Gamma Irradiation as an Intervention Treatment to Inactivate Escherichia coli

O157:H7 in Freshly Extracted Apple Juice

Copyright $\odot 2019$

by Dielle Aurelia Fernandes 


\section{ACKNOWLEDGEMENTS}

This thesis is dedicated to my parents and all my friends who have supported me through this journey. I would like to thank my thesis advisor Dr. Anuradha Prakash for her continuous guidance and motivation, and my thesis committee for their support. 


\begin{abstract}
Use of Gamma Irradiation as an Intervention Treatment to Inactivate Escherichia coli O157:H7 in Freshly Extracted Apple Juice

by Dielle Aurelia Fernandes
\end{abstract}

Escherichia coli $\mathrm{O} 157: \mathrm{H} 7$ can contaminate dropped apples used for juicing via contact with manure or fecally tainted irrigation water and attach to the flesh of the apple through bruises and wounds where surface sanitizers are not effective. The goal of this project was to determine the efficacy of gamma irradiation at the maximum allowed dose of $1000 \mathrm{~Gy}$ to inactivate Escherichia coli $\mathrm{O} 157$ : $\mathrm{H} 7$ in whole apples used for juicing. Whole apples were punctured to simulate wounds which were then inoculated with an outbreak strain of E.coli $\mathrm{O} 157: \mathrm{H} 7$ and subjected to gamma irradiation at doses upto $1000 \mathrm{~Gy}$. The D-value of the E.coli $\mathrm{O} 157: \mathrm{H} 7$ strain was $334 \mathrm{~Gy}$ indicating that irradiation at 1000 Gy would result in a 3-log reduction of this pathogen. Contaminated apples were also stored for 3 weeks at refrigerated temperature during which time E.coli $\mathrm{O} 157: \mathrm{H} 7$ survived but did not grow. The inoculated apples were juiced, and the juice was stored up to $72 \mathrm{~h}$. There was no change in counts of E.coli $\mathrm{O} 157: \mathrm{H} 7$ in the juice from the control apples, but irradiation at >600 Gy reduced counts by $>3$ logs, and survivors were not detected after $72 \mathrm{~h}$ storage. Sensory testing of juice treated at $652 \mathrm{~Gy}$ indicated consumers could tell the difference from control juice, due mostly to greater sweetness of the juice from irradiated apples. These results show that E.coli $\mathrm{O} 157: \mathrm{H} 7$ can easily survive in bruised apples and the juice made from them. Irradiation at $1000 \mathrm{~Gy}$ can provide significant lethality of E.coli O157:H7 in apples and juice conferring a greater level of safety without negative effects on sensory quality. 
Keywords: D-value, sensory, E. coli O157:H7, irradiation, apple juice 


\section{TABLE OF CONTENTS}

ACKNOWLEDGEMENTS iv

ABSTRACT ..v

TABLE OF CONTENTS ....................................................................................... vii

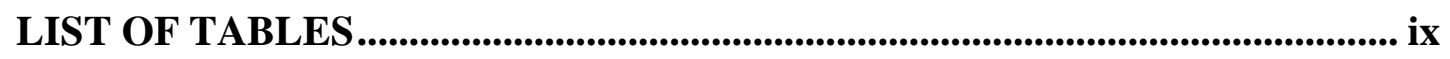

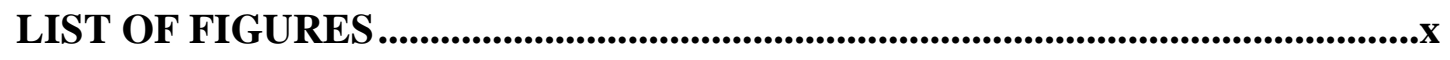

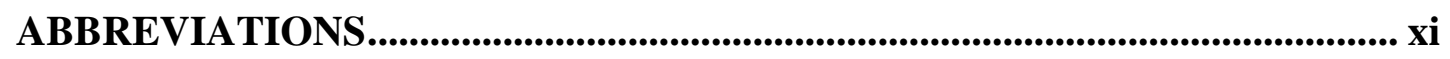

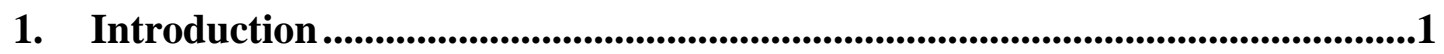

2.Review of Literature.................................................................................................4

2.1 Pathogenicity of Escherichia coli $0157: H 7$....................................................4

2.2 Contamination of apples and apple juice ...................................................

2.3 Attachment of E.coli $\mathrm{O} 157: \mathrm{H} 7$ to fruit tissue .................................................

2.4 Internalization of E.coli $\mathrm{O} 157: \mathrm{H} 7$ into apples. ...........................................

2.5 Effect of irradiation on pathogen inactivation ............................................

2.6 Effect of irradiation on apple quality ...................................................... 10

2.7 Regulations associated with fresh juice processing .........................................11

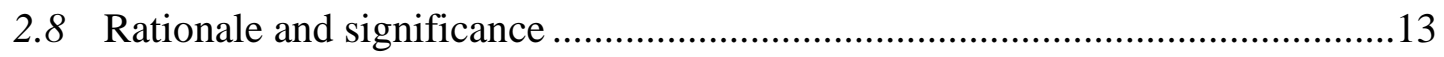

Materials and methods 14

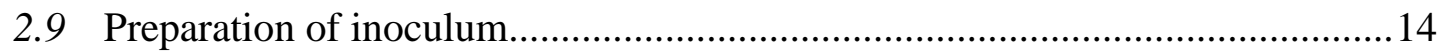

3.1.1 Preparation of apples and inoculation ............................................14

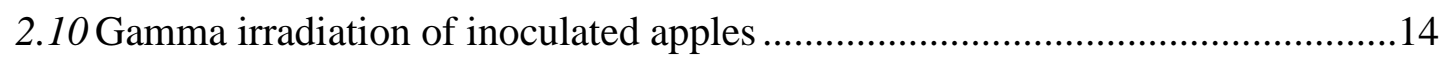

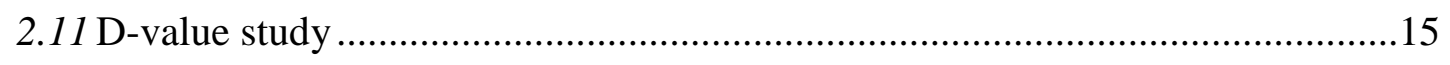

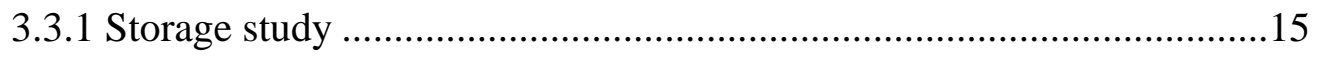

3.3.2 Survival of E.coli $\mathrm{O} 157: \mathrm{H} 7$ in juice ..............................................15

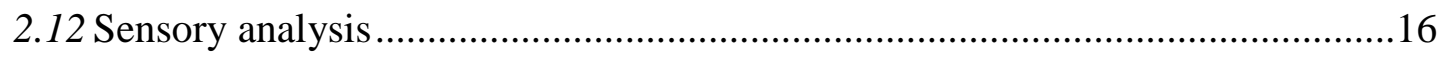

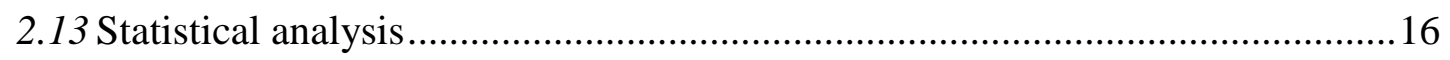

3. Results and Discussion ..........................................................................17 
4. Conclusion.............................................................................................................24

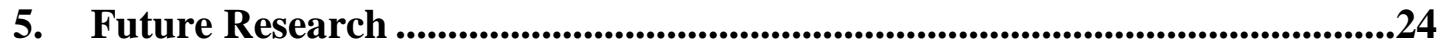

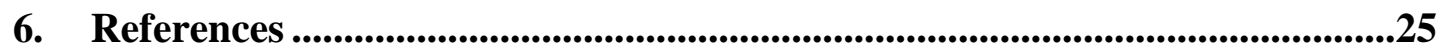




\section{LIST OF TABLES}

Table 1. Outbreaks associated with fresh fruit juice which occurred from 2007-2015

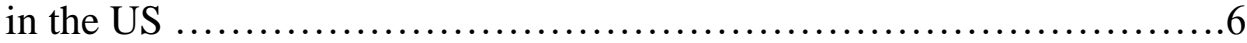




\section{LIST OF FIGURES}

Figure 1. Log reduction of the outbreak strain of E.coli $\mathrm{O} 157: \mathrm{H} 7$ determined using TC-SMAC agar. Each data point represents the average of countable plates from four apples 19

Figure 2.1. Survival of outbreak strain of E.coli $\mathrm{O} 157: \mathrm{H} 7$ in irradiated apples after storage for a period of 0 and 3 weeks from Trial 1 and

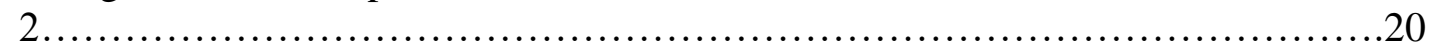

Figure 3.1: Survival of outbreak strain of E.coli $\mathrm{O} 15: \mathrm{H} 7$ in juice stored upto $72 \mathrm{~h}$ produced from irradiated apples kept in refrigerated storage for 3 weeks from Trial 1

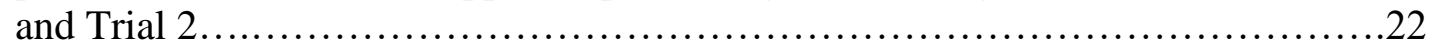




\section{LIST OF ABBREVIATIONS}

FDA: Food and Drug Administration 


\section{Introduction}

Consumers have increased their intake of juices from fruits and vegetables in part due to continued interest in fresh/organic foods and promotion of healthy eating habits by the government (Kahraman et al., 2017). The FDA requires fruit juice processors to achieve a 5log reduction of the most resistant microorganism that may occur in the juice of the fruit, except citrus, in which case the fruit may also be treated (FDA, 2018). Thus, most prepackaged juice in the U.S. is thermally or high pressure pasteurized to kill pathogenic bacteria. However, retail establishments that produce juice for direct sale to consumers are not covered under these regulations. Thus, freshly squeezed juice served at juice bars, farmer's markets, cider mills, and such, and sold by the glass does not receive lethal treatments and may contain harmful bacteria that can cause serious illness (FDA, 2018).

Apple juice or cider has been implicated in a large number of outbreaks associated with E.coli O157:H7. The latest outbreak of E.coli O157:H7 occurred in November 2018 in which Mountain Man Market of Cana, Virginia issued a recall of its $1 / 2$ gallon containers of unpasteurized apple cider due to potential E.coli O157:H7 contamination (VDACS, 2018). The second most recent outbreak occurred in Kansas at an annual cider mill festival where seven people were infected with E.coli O157:H7 after consumption of unpasteurized apple cider from the mill (Beach, 2016). Two other E.coli O157:H7 related outbreaks occurred in November 2012 in Mitchell Farm, Michigan and in 2010 in Baugher's Farm and Orchard, Maryland both involving the hospitalization of adults and children after the consumption of unpasteurized apple cider (Stearns, 2015). Between 1974-2014, Escherichia coli O157:H7 was implicated in 22 out of 48 outbreaks associated with freshly squeezed or unpasteurized fruit juice (Martinez-Gonzales and Castillo, 2016). In 1996, Escherichia coli O157:H7 was associated with a large multi-state outbreak related to the consumption of unpasteurized apple juice produced by Odwalla company with 60 reported cases in California, Colorado and Washington in the US and 10 cases in British Columbia, Canada including 1 death and 25 hospitalizations (Marler, 2013). An investigation into the source of the outbreak determined that the proximity of deer to the apple orchard as well as the use of damaged apples caused the contamination of apples used for juicing (CDC, 1996). These outbreaks highlight the safety concerns related to freshly squeezed or unpasteurized apple juice and 
cider.

E. coli $\mathrm{O} 157: \mathrm{H} 7$ is an acid-tolerant pathogen commonly present in the gastrointestinal tract of cattle and is shed in their feces. The apples used for juice production often include apples that fall to the ground known as 'drop apples' (Sapers et al., 1999). These drop apples can become contaminated with $E$. coli $\mathrm{O} 157: \mathrm{H} 7$ by coming into contact with animal droppings or contaminated water used for washing the apples (Montibus et al., 2016). Other than washing the apples with water and sanitizers, apples used for juicing are not subject to any lethal treatment. Contaminated water can infiltrate the fruit through the calyx or stem end and allow for the internalization of viable E. coli $\mathrm{O} 157: \mathrm{H} 7$ cells. E. coli $\mathrm{O} 157: \mathrm{H} 7$ cells also preferentially attach to puncture wounds and form aggregates in damaged apple crevices (Burnett et al., 2000). This is likely due to the adhesion of E. coli O157:H7 to the hydrophilic apple tissue as opposed to the hydrophobic intact apple skin. For these hard to reach microorganisms, sanitizers associated with whole produce do not reduce microbial populations by more than a few $\operatorname{logs}$ because of the inability of the treatments to kill microbes present in internal areas of the fruit (Burnett and Beuchat, 2001). Although apple juice with its acidic $\mathrm{pH}$ of $<4.0$ may not allow for the active growth of pathogens like E.coli O157:H7, the environment allows for pathogen survival (Chung et al., 2018).

Ionizing radiation is highly effective in eliminating pathogenic microorganisms and improving food safety (Kilonzo Nthenge, 2012). Irradiation is a volumetric treatment; the energy can penetrate through the fruit and eliminate bacteria that have been internalized and that are difficult to eliminate by surface treatments such as washing. A major advantage of using irradiation for fresh fruit is its minimal impact on organoleptic properties, in large part because it is a cold treatment.

Low dose irradiation has been shown to decrease E. coli O157:H7 in apple juice (Buchanan et al., 1998; Hong et al., 2014) however, there has been no research conducted on the survival of Escherichia coli O157:H7 in juice made from irradiated whole apples. Irradiation of juice is not permitted under current FDA regulation for food irradiation; however the law allows for treatment of fresh produce with doses up to 1000 Gy to inhibit maturation and prevent arthropod pests, but not for microbial reduction (FDA, 2018). This research seeks to determine whether low dose irradiation can potentially reduce the risk of microbial contamination associated with apples used for freshly pressed juice. 
The goals of this study were to determine the reduction of E.coli O157:H7 in whole apples at the FDA limit of $1000 \mathrm{~Gy}$, to determine the survival of E.coli O157:H7 in juice produced from irradiated apples, and to determine the sensory quality of juice produced from irradiated apples. 


\section{Review of Literature}

\subsection{Pathogenicity of Escherichia coli O157:H7}

Consumers prefer freshly squeezed apple juice for consumption as compared to heat pasteurized apple juice (Huang et al., 2018). With this increased consumption of minimally processed apple juice, the risk of microbial contamination by E. coli $\mathrm{O} 157: \mathrm{H} 7$ in apples is very high through fecal contamination of irrigation water. This is due to the presence of this pathogen in the gastro-intestinal tract of healthy cattle which can be shed through feces (Stopforth et al., 2004).

Despite being present in the gastro-intestinal tract of cattle, Escherichia coli O157:H7 does not affect them due to the lack of globotriaosylceramide (Gb3) intestinal receptors which are present in humans. This pathogen binds to the $\mathrm{Gb} 3$ receptors in the large intestine and enters the vascular system via endocytosis. Endocytosis of the pathogen is followed by inflammation of the intestine which causes severe abdominal pain with cramps and is the first symptom of Escherichia coli O157:H7 infection. Enterohemorrhagic strain E. coli O157:H7 causes Hemolytic Uremic Syndrome (HUS), a severe form of hemorrhagic colitis, and systematic destruction of red blood cells in the human kidney and brain cells. E. coli O157:H7 also produces a shiga toxin which blocks protein synthesis by damaging the ribosomal DNA. The pathogen is of major concern due to its pathogenicity, low infectious dose and ability to thrive in extra-intestinal environments (Ferens and Hovde, 2011).

\subsection{Contamination of apples and apple juice}

Freshly squeezed fruit juice generally does not involve a step in the juice making process to reduce bacterial load (Hatab et al., 2016). Since fresh or cold pressed juices are untreated prior to consumption, they are more susceptible to microbial contamination and apple juice contaminated with E.coli $\mathrm{O} 157: \mathrm{H} 7$ has resulted in 22 outbreaks between 1974-2014 (Martinez-Gonzales and Castillo, 2016). This microorganism has demonstrated the ability to survive and resist thermal treatments in acidic beverages like apple juice when gradually subjected to acidic $\mathrm{pH}$, thus negating the previous assumptions that Escherichia coli O157:H7 is unable to survive under acidic conditions (Usaga et al., 2014). 
The following factors have been implicated in fresh juice related outbreaks; lack of hygiene, use of dropped fruit, inadequate washing of the fruit, use of untreated manure and proximity of deer or cattle (Martinez-Gonzales and Castillo, 2016). Also, Hatab and others found that E.coli $\mathrm{O} 157: \mathrm{H} 7$ survived in fresh juice (fruit and vegetable blend containing apple juice) with a pH of 3.5 stored at $4^{\circ} \mathrm{C}$ for 4 days (Hatab et al., 2016) indicating that refrigeration is not a barrier for survival of this organism. This is concerning since $\mathrm{pH}$ and refrigeration are commonly used in hurdle technology (Chung et al., 2018).

Previously, the acidity of fruit juice was thought to be a barrier against pathogenic microorganisms until an outbreak of E.coli O157:H7 occurred in 1991 due to freshly pressed apple cider (Vojdani et al., 2016). The occurrence of freshly pressed juice outbreaks from 1991-1996 stimulated new regulations by the FDA in 1998 where fresh juice processors were required to label untreated packaged juice as unpasteurized and a potential source of pathogens. Following this, CDC reported 13 outbreaks associated with fresh juice from 19992005 and the FDA established the 5-log reduction performance standard where fresh juice was required to be treated with a processing method which effectively resulted in a 5-log reduction of pertinent pathogen. This regulation was fully implemented by 2004 (Vojdani et al., 2016). Pertinent pathogen has been defined by the FDA as the most resistant microorganism of public health concern that may occur in the juice. It varies with the juice and type of treatment. Typically, the pertinent pathogens found in juice are E.coli O157:H7, Salmonella and Cryptosporidium parvum. However, the 5-log reduction regulation is not applicable to retail establishments. As per the FDA, retail establishments are those operations that store, prepare, serve and sell juice directly to consumers (FDA, 2018).

The following table lists the reported outbreaks associated with freshly squeezed juice which occurred after the establishment of the FDA Juice HACCP regulations: 
Table 1: Outbreaks associated with fresh fruit juice which occurred from 2007-2015 in the US (Vojdani et al., 2016).

\begin{tabular}{|c|c|c|c|c|c|}
\hline Date & Causative agent & $\begin{array}{l}\text { Illnesses } \\
\text { reported }\end{array}$ & Product & Pasteurization & Location \\
\hline October 2015 & E. coli O157:H7 & 30 & Apple cider & Unknown & Illinois \\
\hline October 2014 & E. coli O157:H7 & 3 & Apple cider & Unpasteurized & Canada \\
\hline October 2013 & Cryptosporidium & 11 & Apple cider & Unpasteurized & Iowa \\
\hline October 2012 & E. coli O157:H7 & 3 & Apple cider & Unpasteurized & Michigan \\
\hline $\begin{array}{c}\text { December } \\
2011\end{array}$ & Norovirus & 14 & Fruit punch & Unknown & Wisconsin \\
\hline October 2011 & Cryptosporidium & 4 & Apple cider & Unpasteurized & Ohio \\
\hline October 2011 & $\begin{array}{l}\text { C. parvum and } \\
\text { E. coli } 0111\end{array}$ & 14 & Apple cider & Unpasteurized & Minnesota \\
\hline $\begin{array}{l}\text { September } \\
2011\end{array}$ & Unknown & 3 & Apple cider & Unpasteurized & Ohio \\
\hline June 2011 & Norovirus & 80 & Lemonade & Unknown & Georgia \\
\hline February 2011 & Norovirus & 207 & Juice & Unknown & Georgia \\
\hline January 2011 & Norovirus & 18 & $\begin{array}{l}\text { Orange } \\
\text { juice }\end{array}$ & Unknown & California \\
\hline Oct -Nov 2010 & E. coli O157:H7 & 7 & Apple cider & Unpasteurized & Maryland \\
\hline June 2009 & Norovirus & 10 & $\begin{array}{l}\text { Orange } \\
\text { juice }\end{array}$ & Pasteurized & $\begin{array}{c}\text { Connectic } \\
\text { ut }\end{array}$ \\
\hline March 2009 & Norovirus & 189 & Lemonade & Unknown & Illinois \\
\hline October 2008 & E. coli O157:H7 & 7 & Apple cider & Unpasteurized & Iowa \\
\hline October 2007 & E. coli O157:H7 & 9 & Apple cider & Unpasteurized & $\begin{array}{c}\text { Massachu } \\
\text { setts }\end{array}$ \\
\hline April 2007 & Norovirus & 10 & Lemonade & Unknown & Maryland \\
\hline
\end{tabular}


Acai,

banana,

March 2007 Hepatitis A 3 strawberries Unknown Florida

, sugarcane

juice

\subsection{Attachment of E.coli $\mathrm{O} 157: \mathrm{H} 7$ to fruit tissue}

As found by Hassan and Frank (2004), the bacterial flagellae, fimbriae and exopolysaccharides may be involved in adhesion of the pathogen to the fruit. The extracellular polymer composition of the microbial cell plays a role in attachment to produce surfaces where a higher protein: sugar ratio facilitates increased attachment. However, the composition of the extracellular polymer (sugar + protein content) of the microbial cells is dependent upon the bacterial growth conditions (Mayton et al., 2019). Growth of E.coli $\mathrm{O} 157: \mathrm{H} 7$ in TSB with its dextrose content facilitates capsule production which increases the bacterial cell hydrophilicity. Hence, E. coli $\mathrm{O} 157: \mathrm{H} 7$ has been shown to preferentially attach to hydrophilic apple tissue through wounds and cracks as opposed to intact hydrophobic cuticle (Hassan and Frank, 2004).

Burnett and others found that E.coli $\mathrm{O} 157: \mathrm{H} 7$ cells preferentially attached to damaged tissue surrounding puncture wounds in the warm apple and formed aggregates in damaged apple crevices. These aggregates were found upto a depth of $70 \mu \mathrm{m}$ below the tissue surface (Burnett et al., 2000). In the same study, it was found that the calyx region of apples is more likely to facilitate the infiltration of the pathogen due to capillary action of contaminated water. Deep crevices resulting from torn apple tissue in particular, held biofilm like matrices of the E.coli O157:H7 cells (Burnett et al., 2000).

E.coli produces exo polysaccharides which helps in the formation of biofilms and facilitates its survival under environmental stresses (Ryu and Beuchat, 2005). E. coli O157:H7 cells have been shown to be more adhesive and aggregate to form a biofilm when subjected to stressful environments like nutrient-restricted conditions. The survival and adaptability of $E$. coli $\mathrm{O} 157: \mathrm{H} 7$ in acidic conditions in addition to its virulence and resistance to stress is potentially the reason for the multiple outbreaks and product recalls associated with the pathogen. 


\subsection{Internalization of E.coli O157:H7 into apples}

E. coli $\mathrm{O} 157: \mathrm{H} 7$ is an acid-tolerant pathogen commonly present in the gastrointestinal tract of cattle and is shed in their feces. The apples used for juice production often include apples that fall to the ground known as 'drop apples' (Dingman, 2000). Drop apples can come into contact with animal droppings and become contaminated with E. coli O157:H7.Alternately, contaminated water used for washing the apples can also lead to transfer of Escherichia coli O157:H7 to the apples (Montibus et al., 2016).

Contaminated wash water can infiltrate the fruit through the calyx region and allow for the internalization of viable $E$. coli $\mathrm{O} 157: \mathrm{H} 7$ cells. There is a greater chance of E.coli O157:H7 internalization when warm harvested apples are placed in cooler wash water/ sanitizer solutions (Burnett et al., 2000). This is due to the gas law stating that as the temperature of the fruit decreases, their tissue gases exert a reduced pressure thus causing the hydrostatic and atmospheric forces on the fruit to equilibrate with internal pressure, resulting in ingress of water (Burnett et al., 2000). In this study, E.coli O157:H7 cells entered the fruit through the calyx region to infiltrate the apple core via the floral tube when warm apples $\left(25^{\circ} \mathrm{C}\right)$ were placed in cooler water i.e. under negative temperature differential imitating the process used to wash harvested fruit. Confocal laser scanning microscopy revealed a greater number of the pathogen was observed in the apple core as compared to the apple skin surface. The entry of the pathogen to the apple core through the calyx region is of great concern since the fruit encounters contaminated irrigation water and is exposed to direct contact with cattle fecal matter and surface treatments like sanitizers are ineffective in removing the pathogens (Burnett et al., 2000).

Wisniewsky and others (2000) measured the reduction of E.coli O157:H7 cells surface inoculated on whole apples using three sanitizers, peroxyacetic acid, chlorine dioxide and chlorine-phosphate buffer solution. Water alone decreased viable cell counts by almost 2 logs, peroxyacetic acid and chlorine-phosphate buffer solution achieved a 3-log reduction, and chlorine dioxide achieved a 2-log reduction. Thus, while these sanitizers did achieve a modest reduction of surface cells, they speculated that surface sanitation would be ineffective in inactivating internalized organisms as might be found in bruised apples which are often used in making cider (Wisniewsky et al., 2000). 
In addition, E.coli O157:H7 being a Gram Negative pathogen can survive in water containing organic matter (Moriarty et al., 2019) and hence has a strong survival in contaminated irrigation or wash water. E. coli $\mathrm{O} 157: \mathrm{H} 7$ has been shown to survive in a starvation state in the presence of a nutrient scarce environment and become resistant. This has been attributed to the pathogen's protective genetic response corresponding to the production of cellular resistance to chemical and physical challenges (Hong et al., 2014).

\subsection{Effect of irradiation on pathogen inactivation}

Irradiation is highly effective on pathogen reduction in produce. However, the microbial resistance of pathogens like E.coli $\mathrm{O} 157: \mathrm{H} 7$ to irradiation is dependent upon the prior physiological stress of the pathogen (Hong et al., 2014). Buchanan and others (1998) found that subjecting E.coli $\mathrm{O} 157: \mathrm{H} 7$ strains to acid resistance prior to gamma irradiation increased the D-value from 120 - 210 Gy (non-acid-adapted) to 220 - 310 Gy for acid adapted cells. The growth of E.coli $\mathrm{O} 157: \mathrm{H} 7$ in acidic $\mathrm{pH}$ does not deter its survival but instead aids in its resilience to radiation.

Similarly, Hong and others (2014) studied the effect of E.coli O157:H7 growth phase, on the radiation resistance in apple juice. The following D values for E.coli O157:H7 in apple juice have been observed : 160 , 190 and 330 Gy respectively for E.coli O157:H7 cells grown in Tryptic Soy Broth (TSB) at $35^{\circ} \mathrm{C}$ until $0.10-1.15$ OD was reached (exponential phase), $\mathrm{TSB}$ at $35^{\circ} \mathrm{C}$ for $24 \mathrm{~h}$ (stationary phase) and $\mathrm{TSB}$ at $35^{\circ} \mathrm{C}$ for $24 \mathrm{~h}$ followed by storage in $0.85 \%$ saline at $25^{\circ} \mathrm{C}$ for 10 days (starved cells) (Hong et al., 2014). The highest D-value among the E.coli O157:H7 strains was observed in the starved cells since they have a greater ability to resist the effects of irradiation as compared to exponential or stationary phase cells. In addition, with an initial population of $2.0 \times 10^{7}$ $\mathrm{cfu} / \mathrm{mL}, 700 \mathrm{~Gy}$ of irradiation reduced populations by $2.2 \mathrm{logs}$ for starved cells as compared to 4.32 and $3.74 \log$ cycles for the exponential and stationary phase cells respectively (Hong et al., 2014). These data suggest that, starved cells have the ability to metabolize nutrients but may not be able to multiply and form colonies (Hong et al., 2014). Hence E.coli $\mathrm{O} 157: \mathrm{H} 7$ can potentially survive but not multiply in nutrient scarce environments.

Different D-values have been previously observed for E.coli O157:H7: 300 - 450 Gy in lettuce where the irradiation dose was variety-specific (Niemira, 2008), 1100 Gy in 
spinach when irradiated with X-ray (Mahmoud et al., 2016), 400 Gy with e-beam irradiation (Neal et al., 2016), 400 for cucumber and $410 \mathrm{kGy}$ for blanched and seasoned spinach and undetectable at 1000 Gy dose for burdock spinach (Young Lee et al., 2006). This data indicates that the $\mathrm{D}$ values are different based on the produce and that doses of 1000 Gy can result in a 3-5 log reduction.

\subsection{Effect of irradiation on apple quality}

Food irradiation is the use of any of the three types of radiation: electron beam, $\mathrm{x}$-ray, or gamma irradiation, where the food molecules absorb the radiation energy. The amount of irradiation in the form of energy absorbed by the food is measured in Gray where 1 Gray $=1$ Joule $/ \mathrm{Kg}$.

The World Health Organization and Food and Agriculture Organization have endorsed irradiation since it enhances food safety by eliminating harmful micro-organisms (BarkaiGolan and Follett, 2017). Due to its benefits in inhibiting maturation and insect infestation, the FDA has approved ionizing radiation as a food additive for the processing of fresh produce upto levels of $1 \mathrm{kGy}$ (FDA, 2019).

Irradiation is effective due to its ability to inactivate microbial populations present on the surface of the fruit as well as in the core of the fruit (Kilonzo Nthenge, 2012). This is a particularly significant advantage and can help reduce pathogens which have been internalized in the fruit.

Irradiation generally has no negative impacts on the organoleptic properties of fresh produce at doses upto $1000 \mathrm{~Gy}$ (Jeong and Kang, 2017) making it nearly impossible to tell if fruit has been irradiated. 
In a study conducted by Fan and others (2005), apple slices treated with $7 \%$ calcium carbonate for anti-browning and irradiated at a dose of $1000 \mathrm{~Gy}$ had firmness of $1.80 \pm$ $0.31 \mathrm{~kg}$ at 1 week storage which is similar to the non-irradiated apple slices firmness value of $1.85 \pm 0.35 \mathrm{~kg}$ at 3 week storage. In addition to firmness, the titratable acidity, $\mathrm{pH}$ and ascorbic acid of sliced apples irradiated at doses 500 Gy and 1000 Gy had no significant difference in comparison to that of non-irradiated apples (Fan et al., 2005).

Irradiation at doses higher than $800 \mathrm{~Gy}$ has an effect on the firmness of apples however this is dependent on the storage period after irradiation, since the longer storage time is directly proportional to the reduced firmness in apples due to pectin breakdown. However, there is no loss in sucrose, fructose and glucose content in addition to no loss in the color attributes of apples irradiated at $1000 \mathrm{~Gy}$ in comparison with controls (Jung et al., 2016). Mostafavi and others (2012) found that at gamma irradiation doses of 900 - 1200 Gy there were significant losses in apple moisture content over storage period of 6 and 9 months. However, 3 month storage of 900 - 1200 Gy irradiated apples had no significant effect on moisture content hence suggesting the 3 months of storage should not affect quality. Among other fruit quality parameters tested, the total soluble solids which are indicative of the sugar content, increased with a decrease in moisture content of the apples irradiated at 900 and 1200 Gy with a TSS value of 16.28 and $19.12 \%$ respectively after a 9-month storage period. An increase in phenolic and subsequently anti-oxidant content of the apples irradiated at 300 and $600 \mathrm{~Gy}$ was observed after a storage period of 6 months. This indicates that the anti-oxidant power of apples is not harmed but is potentially enhanced by irradiation.

\subsection{Regulations associated with fresh juice processing}

After the multi-state Odwalla apple juice outbreak of 1996 which affected 64 persons with more than a dozen developing hemolytic uremic syndrome (HUS) and 1 fatality (Marler, 2013), the FDA implemented a new juice labelling regulation starting in 1998. This was followed by the $5 \log$ reduction performance standard effective from 2004. As per the Juice HACCP guidelines, fresh packaged juice is required to undergo pathogen reduction treatment resulting in a $5-\log$ reduction i.e. $10^{5}$ of the pertinent pathogen associated with the juice; pertinent pathogen being the most resistant microorganism. If 
the juice is untreated with such a microbial reduction treatment, a warning label statement on the juice container must state that the product has been not been pasteurized and hence can contain bacteria which can cause serious illness in consumers (FDA, 2018).

Retail juice processors are those which store, prepare and serve freshly squeezed juice directly to the consumers and hence are not subject to FDA juice HACCP regulation (FDA, 2018). Since juice bars and other retail juiceries serve fresh juice to consumers by the glass, they do not fall under the FDA 5-log reduction regulation and hence they are not required to treat the fruit or the juice with a processing method to inactivate the pertinent pathogen. The current FDA regulation for irradiation of produce allows treatment of apples with doses upto $1000 \mathrm{~Gy}$ to inhibit maturation and prevent arthropod pests, but not microbial reduction (FDA, 2019). However, these doses can potentially reduce the risk of microbial contamination associated with apples used for freshly pressed juice. 
2.8 Rationale and Significance

Objectives:

1. To determine the reduction of E. coli $\mathrm{O} 157: \mathrm{H7}$ on whole apples at the FDA limit of 1000 Gy.

2. To determine the survival of $E$. coli $\mathrm{O} 157: \mathrm{H} 7$ in juice from irradiated apples.

3. To determine the sensory quality of juice from irradiated apples.

Hypothesis: Irradiation at doses upto $1000 \mathrm{~Gy}$ will inactivate E. coli O157:H7 inoculated on whole apples and can thus be used as a treatment method for processing whole apples prior to juicing.

Justification: The current use of anti-microbials and sanitizers like chlorine and peroxyacetic acid to wash the whole apples for juice production are ineffective in reducing the microbial population of Escherichia coli $\mathrm{O} 157: \mathrm{H} 7$ by 5 logs. Irradiation is suitable for the treatment of fresh produce given that it is a non-thermal treatment and its ability to inactivate internalized pathogens. Till date, there has been no research conducted on the irradiation of whole apples for juicing to inactivate Escherichia coli O157:H7. 


\section{Materials and methods}

3.1. Preparation of inoculum: Outbreak strain FNW13b88 of enterohemorrhagic Escherichia coli O157:H7 from the 1996 Odwalla unpasteurized apple juice outbreak was obtained on two slants from the Food and Drug Administration Pacific Northwest Lab in Bothell, WA and subcultured on Tryptic Soy Agar Yeast Extract (TSAYE). Following incubation, the subculture was stored at $4^{\circ} \mathrm{C}$ until further use. For the preparation of the inoculum, each strain was transferred using a loop into $4 \mathrm{~mL}$ of tryptic soy broth (TSB) and incubated at $37^{\circ} \mathrm{C}$ for $18-24$ hours in a shaking incubator. Inoculum was prepared by centrifuging (accuSpin ${ }^{\odot} 1 \mathrm{R}$, Fisher Scientific, Waltham, MA) the overnight growth of $E$. coli $0157: \mathrm{H} 7$ in TBS at $1160 \times \mathrm{g}$ for $15 \mathrm{~min}$ and resuspending the bacterial pellet in Butterfield's Phosphate Buffer. Final inoculum concentration was determined by plating dilutions on TC-SMAC and incubating at $37^{\circ} \mathrm{C}$ for $24 \mathrm{~h}$.

3.1.1. Preparation of apples and inoculation: 40 Gala apples (Malus domestica Gala) without bruises and uniform skin were purchased from the local grocery store in Orange, California and transported to Chapman University, Orange, California. The apples were sanitized by dipping them in a 2000 ppm bleach solution for 1 minute followed by immersion in tap water for a minute (Buchanan et al., 1999) and then air dried. Once dry, each apple was punctured using the TA.XT. Plus Texture Analyzer (Model TA. XT Plus, Stable Micro Systems, Inc., Surrey, UK) equipped with Exponent 6.1.10.1 software. A $3 \mathrm{~mm}$ cylinder probe was used to create eight evenly spaced $8 \mathrm{~mm}$ deep punctures on the shoulder of the apple for a puncture volume of $57 \mu \mathrm{L}$. The punctured apples were allowed to dry for $2 \mathrm{~h}$ to allow the juice in the punctures to dry. In a biosafety cabinet, $50 \mu \mathrm{L}$ of the inoculum $(9.87 \mathrm{cfu} / \mathrm{ml}$ and $10.08 \mathrm{cfu} / \mathrm{ml}$ for Trial 1 and 2 respectively) was pipetted into each puncture on the apple ( $400 \mu \mathrm{L}$ of inoculum per apple) and allowed to dry for 18-24 hours.

3.2 Gamma irradiation of inoculated apples: The dried inoculated apples were double wrapped in plastic wrap and packed in plastic boxes. The plastic boxes were placed in an insulated cooler and transported to the Nuclear Science Laboratory, Department of Chemistry at University of California, Irvine (14 miles from Chapman University). The 
apples were placed in a circular custom built 3 shelf sample holder with a hole in the center to accommodate the Cesium source when it was lifted into position for treatment. The apples were placed radially around the source, on their sides, so that the shoulder and stem end of each apple faced the source at an equal distance $(100 \mathrm{~mm})$, to ensure that each puncture received equivalent treatment. Previously, dose mapping had been conducted with 12 alanine dosimeters (Farwest Technology, Inc., Goleta, CA) taped on the shoulder of each of 12 apples placed at various locations on the custom fruit holder. The D $\max / \mathrm{Dmin}$ ratio was determined to be 1.16 and the dose rate was $0.84 \mathrm{kGy} / \mathrm{h}$. The uncertainty of the alanine dosimetry was estimated to be $7 \%$. The apples were treated at target doses of 200, 400, 600 and $800 \mathrm{~Gy}$ (seven apples per dose for each trial), and the average absorbed doses were 234, 423, 615, and 819 Gy for Trial 1 and 188, 390, 606, 789 Gy for Trial 2. Non-irradiated apples used as controls were exposed to the same storage and transport conditions as the irradiated apples. The apples were transported back to Chapman University in the insulated cooler and stored at $4^{\circ} \mathrm{C}$ until analysis.

3.3 D value study: Four apples from each dose were analyzed $48 \mathrm{~h}$ following irradiation to determine the irradiation D-value of the outbreak strain. The shoulder section of each apple containing the punctures was cut $(15-20 \mathrm{~g})$ using a sterile knife, placed in a stomacher bag and diluted 10 fold (Dilumat, BioMérieux, Durham, NC) with Butterfield's Phosphate buffer (BPB), and stomached (Stomacher ${ }^{\circledR} 400$ Circulator Lab Blender, Thomas Scientific) for $1.5 \mathrm{~min}$ at 230 RPM. Serial dilutions were made using $9 \mathrm{~mL}$ of Butterfield's phosphate buffer solution and $0.1 \mathrm{~mL}$ of the appropriate dilutions were plated in duplicate on Tellurite-Cefixime Sorbitol MacConkey (TC-SMAC) agar followed by incubation at $37^{\circ} \mathrm{C}$ for $24 \mathrm{~h}$ for enumeration of survivors. A plot of survivors versus dose was created and the $D$ value was calculated as the negative inverse of the slope.

3.3.1 Storage study: The remaining apples were stored for three weeks at $4^{\circ} \mathrm{C}$ and the survival of E. coli $\mathrm{O} 157: \mathrm{H} 7$ was determined using the same enumeration method as detailed above.

3.3.2. Survival of E.coli $\mathrm{O} 157: \mathrm{H} 7$ in juice: Juice was extracted from the three-week stored apples. Since this study used pathogenic E. coli $\mathrm{O} 157: \mathrm{H} 7$, we used a stomacher instead of a juicer to simulate juicing. Stomaching required the addition of liquid, so water was added 
as the diluent. The $\mathrm{pH}$ of the apple juice produced with stomaching with water was 4.29 as compared to 3.85 , the $\mathrm{pH}$ of the juice without added water. To enumerate the survivors, ten-fold dilutions were made using BPB and plated as described previously.

3.4 Sensory Analysis: A discriminative tetrad test was performed with 55 untrained sensory panelists (comprising students, staff and faculty of Chapman University) to determine differences between apple juice produced from control and irradiated apples. For the sensory test, a separate set of non-inoculated apples were irradiated at an absorbed dose of $652 \mathrm{~Gy}$, juiced and stored at $4^{\circ} \mathrm{C}$ for $12 \mathrm{~h}$ prior to the sensory analysis. Panelists were served duplicate samples of approximately $25 \mathrm{~mL}$ of control and irradiated apple juice in sample cups with a cracker and glass of water to cleanse the palette in between samples. RedJade $^{\odot}$ Sensory Software (RedJade Sensory Solutions, LLC 1091 Village Oaks Dr, Martinez, CA 94553 USA) generated 4 blinding codes and the samples were presented to the panelists in a random order to remove any bias. The panelists were asked to select sample codes of two samples that they deemed were the same.

3.5 Statistical analysis: In the D value study, four apples were used as replicates for each dose. In the storage study, three apples were used as replicates for each dose. Appropriate dilutions were plated in duplicate. Countable plates, 25-250 colonies, were averaged with counts expressed as $\log \mathrm{cfu} / \mathrm{g}$. All computations for statistical analysis used the RStudio software program (R Core Team, 2017). Analysis of the apples was performed after a 23day storage period followed by analysis of apple juice stored upto $72 \mathrm{~h}$. Throughout this study, we used a level of significance of $\alpha=0.05$.

Comparison of the mean of E.coli O157:H7 counts in $\log \mathrm{cfu} / \mathrm{g}$ across treatment combinations of irradiation dose and storage days for apples and across treatment combinations of irradiation dose as well as storage hours for apple juice were conducted using two-way analysis of variance (ANOVA). If the results of ANOVA were found to be statistically significant, a Tukey's HSD test was conducted to determine which treatment combinations were significantly different. Results were presented using mean bar plots with error bars and treatments with the same letter on top of each bar are not statistically different $(\mathrm{p}>0.05)$. 


\section{Results and Discussion}

\section{Recovery of E.coli O157:H7 from the surface of the fruit versus flesh:}

The recovery of E.coli $\mathrm{O} 157: \mathrm{H} 7$ inoculated on the surface of the apple versus in flesh punctures was compared (data not shown). The recovery from punctures was $1 \log$ greater than the recovery from the peel surface suggesting that E.coli O157:H7 preferentially attaches to apple flesh versus the peel. The extraction efficiency (cells recovered/cells inoculated) in our study was 69 - 76\% from the flesh versus 59 - $65 \%$ from the peel. In contrast, Dingman (2000) obtained a 30\% extraction efficiency for E.coli O157:H7 from bruised apple tissue.

Burnett and Beuchat (2001) explained that the hydrophobic cuticle on the epidermis of apples presented a barrier to the entry and attachment of microorganisms. However, the presence of stomata, lenticels, broken trichomes and breaks in the skin can facilitate the attachment of bacteria and their migration into the core of the fruit. In another study conducted by Burnett and others, E. coli $\mathrm{O} 157: \mathrm{H} 7$ attached in the form of aggregates mainly at wounds or bruises present in the apple cuticle as compared to the intact surface of the apple cuticle (Burnett et al., 2000).

Fatemi and others (2016) researched the depth of penetration, survival and growth of E.coli $\mathrm{O} 157: \mathrm{H} 7$ into apple punctures and wounds. They found that E.coli $\mathrm{O} 157: \mathrm{H} 7$ inoculated in fresh cut surfaces of Golden Delicious apples penetrated up to $2.8 \mathrm{~mm}$ within 24 hours and increased by 3 logs after 48 hours. The cells multiplied 4 - 8 hours after inoculation increasing by 3 logs after 48 hours. The authors suggested that the ability of the organism to penetrate into the flesh and calyx made commercial sanitizer solutions ineffective on these internalized E.coli $\mathrm{O} 157: \mathrm{H} 7$ and a more efficacious pathogen reduction treatment was needed.

Buchanan and others (1999) found that when refrigerated apples $\left(2^{\circ} \mathrm{C}\right)$ were immersed in solutions containing E.coli $\mathrm{O} 157: \mathrm{H} 7$ bacterial suspension and surface sanitized with chlorinated water, there was only $1-2 \log$ reduction of the bacteria. In the same study, the authors researched the uptake of dye in the fruit, to simulate uptake of contaminated wash water. Dye was taken up by wounds and punctures, indicating that pathogens can enter the 
flesh through bruises on the surface of the fruit. This finding supports Burnett and Beuchat' s study and reiterates that damaged apples harbor greater numbers of E.coli O157:H7 and can further contaminate the juice produced from these apples.

D-value determination: In this study, the average D-value of the outbreak strain of E. coli $\mathrm{O} 157: \mathrm{H} 7$ was calculated as $337 \mathrm{~Gy}$ based on the D-values of Trial 1 (370 Gy) and Trial 2 (303 Gy). The kinetics of inactivation were linear in both cases with $\mathrm{R}^{2}$ values > 0.95 (Figure 1), indicating first order inactivation. No tailing was observed. The resistance of bacteria to irradiation is a function of many factors and small differences between the apples used in the two trials such as moisture content and $\mathrm{pH}$, or environmental differences such as temperature during processing and storage could be responsible for the differences in the $\mathrm{D}$ values between the two trials.

The D-value is similar to that observed by Mahmoud and others (2016) for E. coli O157:H7 on the surface of mangoes (3 log reduction at $1 \mathrm{kGy}$ ), Kong and others (2014) who measured a D value of 370 Gy for E. coli $\mathrm{O} 157: \mathrm{H} 7$ on blueberries, and higher than the $200 \mathrm{kGy}$ observed by Moreira and others (2012) on the surface of cantaloupes. The Dvalues obtained in this study are also higher than D-values, 120 - $210 \mathrm{~Gy}$, for three strains of E.coli O157:H7 in apple juice (Buchanan et al., 1998). However, Buchanan and others found that when the E.coli $\mathrm{O} 157: \mathrm{H} 7$ strains were acid adapted, by growing the strains in TSB plus $1 \%$ glucose, the D values increased to 220 - $310 \mathrm{~Gy}$.

Buchanan and others in 1998 also observed that D values increased as the solids content of the juice increased as measured by absorbance at $550 \mathrm{~nm}$. Turbid juices with high soluble solids corresponded with D values between 330 - $350 \mathrm{~Gy}$. Our D values of 300 - 370 Gy are similar to these values observed for juices with a high solids content.

Hong and others (2014) obtained a D value of $190 \mathrm{kGy}$ for E.coli O157:H7 in store bought clarified, pasteurized apple juice. They observed that starvation of the E. coli O157:H7 cells prior to irradiation resulted in increased radiation resistance. Hong and others grew E. coli $\mathrm{O} 157: \mathrm{H} 7$ cells till they reached the exponential phase or stationary phase. These cells were then starved by storage in saline for a period of 10 days. The Dvalues for a mixture of four strains of $E$. coli $\mathrm{O} 157: \mathrm{H} 7$ cells in the stationary phase in apple juice was found to be $190 \mathrm{~Gy}$ whereas starved cells had a D-value of $330 \mathrm{~Gy}$.

The higher D value for E.coli $\mathrm{O} 157: \mathrm{H} 7$ in our study could also be due to the attachment 
of the E. coli $\mathrm{O} 157: \mathrm{H7}$ cells to the flesh versus the surface. Niemira conducted a study comparing the D values for E.coli $\mathrm{O} 157: \mathrm{H} 7$ on the surface versus internalized into the tissues of various lettuces. The D-values of E.coli $\mathrm{O} 157: \mathrm{H} 7$ were found to be between 330 and $340 \mathrm{~Gy}$ for Boston and Red leaf lettuce homogenates, respectively. For cut lettuce surfaces of Boston and Red leaf lettuce, D-values were $140 \mathrm{~Gy}$ and $120 \mathrm{~Gy}$, respectively (Niemira et al., 2002). The different D values between the lettuce leaf and the lettuce homogenates suggest that the extent of internalization of the pathogen plays a significant role in determining the efficacy of radiation.

The maximum dose of radiation permitted by the FDA for the treatment of fresh produce is $1000 \mathrm{~Gy}$. The average D-value from the two runs was $337 \mathrm{~Gy}$ for this outbreak strain of E.coli $\mathrm{O} 157: \mathrm{H} 7$ indicating that a $\approx 3 \log$ reduction of the bacterial population of the strain can be obtained by irradiation at the maximum permissible limit of $1000 \mathrm{~Gy}$. This level of reduction of cells attached to flesh is higher than could be achieved by washing the apples in sanitizer solutions which can only address cells on the surface of the fruit and achieve a reduction of 1-2 logs (Buchanan et al., 1999).

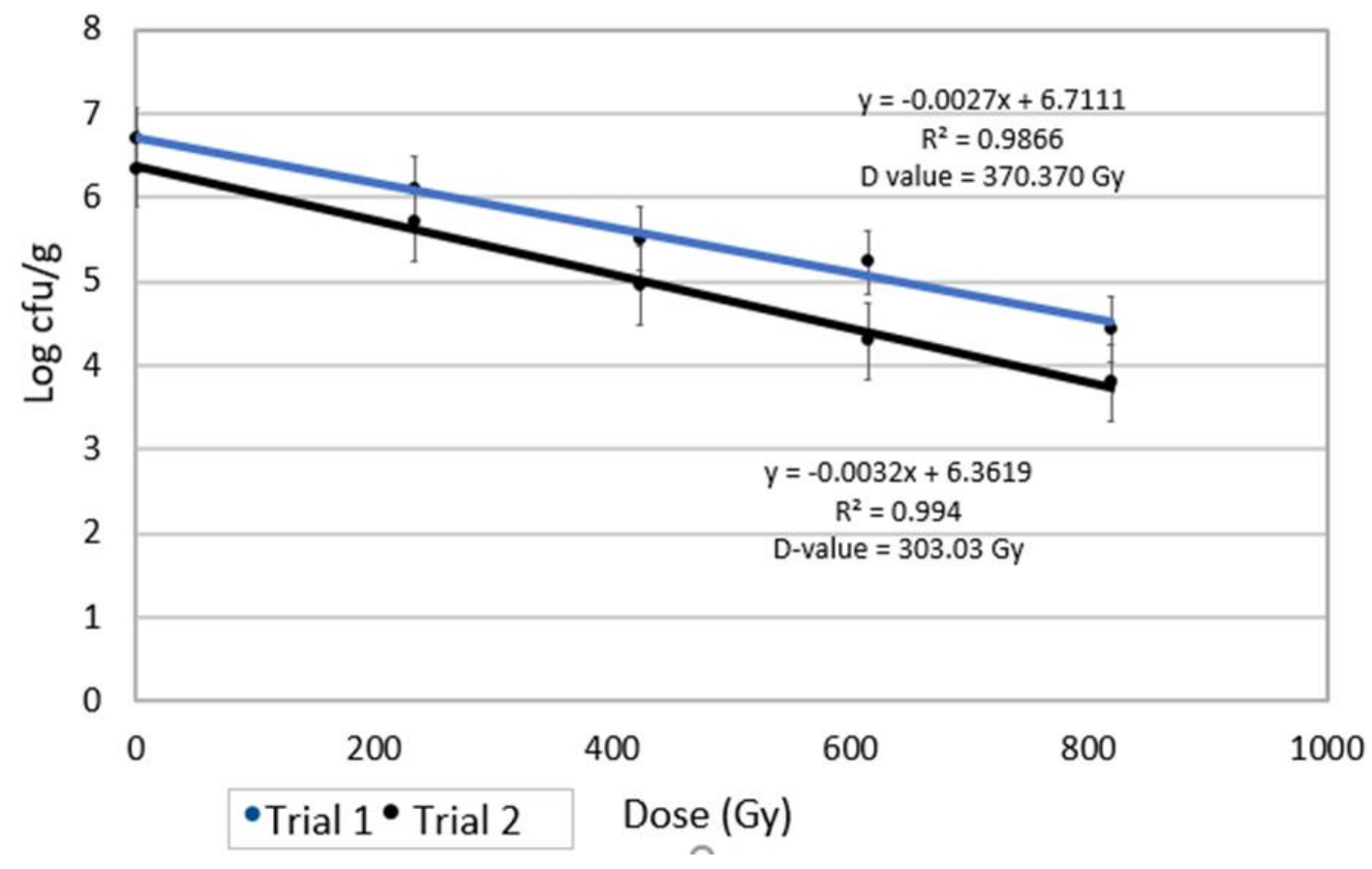

Figure 1: Log reduction of the outbreak strain of E.coli $\mathrm{O} 157: \mathrm{H} 7$ determined using TC-SMAC agar. Each data point represents the average of countable plates from four apples. 
Apple storage study: As depicted in Figure 2.1, E.coli O157:H7 survived during the three week storage but counts declined during storage. In the control apples, counts declined by $\sim 1.8 \operatorname{logs}$ in the first trial, and $\sim 0.8 \log$ in the second trial $(\mathrm{p}<0.05$ ). In the irradiated apples, the decline in counts were similar during storage except at the higher doses, in which the 819 Gy (Trial 1) and 789 Gy (Trial 2) apples at Day 23 showed no detectable counts indicating a $>2 \log$ reduction.

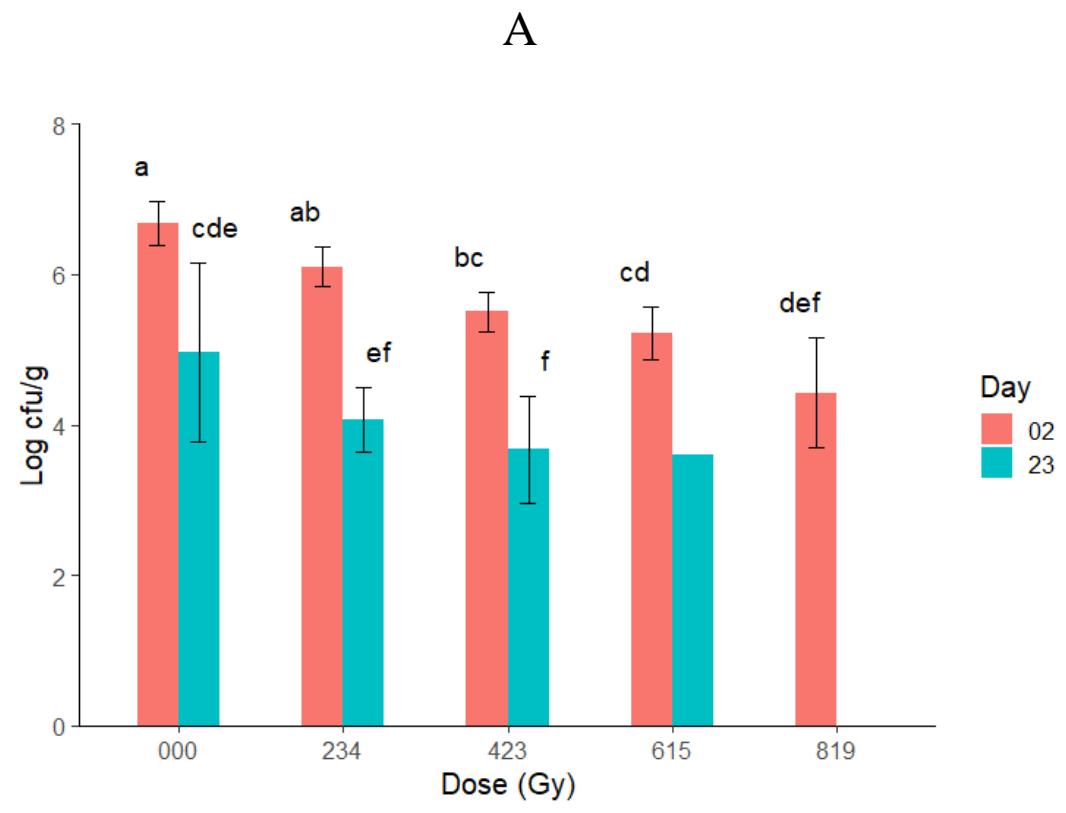

B

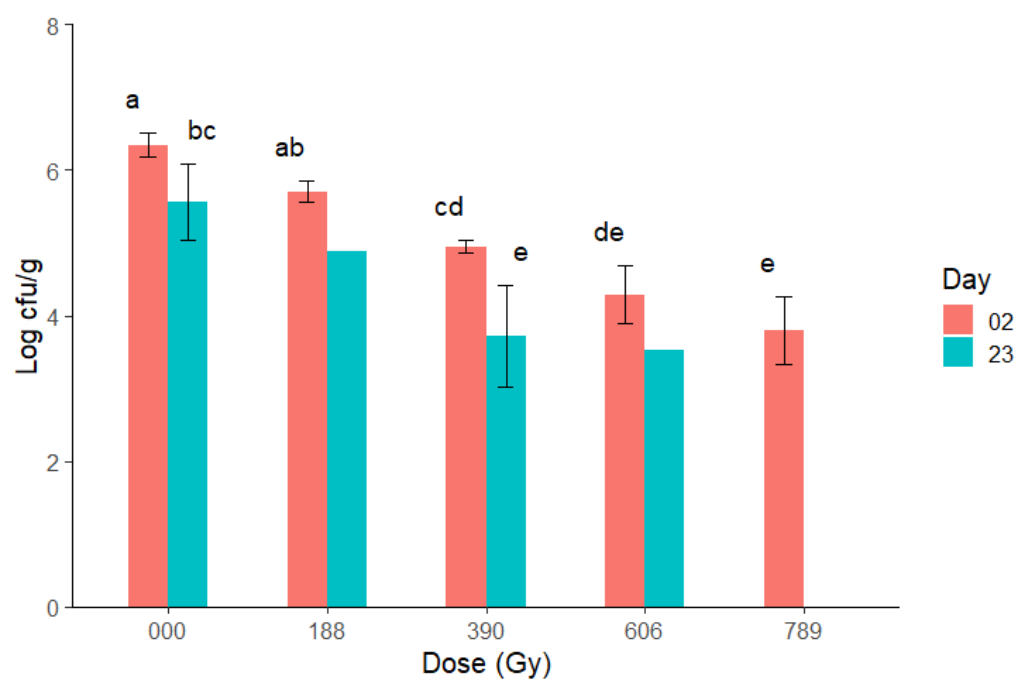


Figure 2.1: Survival of outbreak strain of E.coli $0157: H 7$ in irradiated apples after storage for a period of 0 and 3 weeks from Trial 1(A) and 2(B). Different letters on top of each bar show significant differences $(p<0.05)$ between treatment dose and storage time. Each data point represents the average of countable plates from three apples. **Bars in the graph without error bars have only one data point. No bar present for Day 23819 and 789 Gy since no survivors were obtained.

Previous studies have also shown that E.coli $\mathrm{O} 157: \mathrm{H} 7$ can survive in damaged apple tissue. The retention of E.coli $\mathrm{O} 157: \mathrm{H} 7$ in damaged apples, specifically tree picked and dropped apples was studied by Dingman(2000). Tree picked apples and drop apples were bruised by dropping the apple from a height of $1 \mathrm{~m}$ and the bruises inoculated with E.coli O157:H7 at concentrations of $10^{4}-10^{5} \mathrm{cfu} / \mathrm{mL}$. Within a week of storage at $4^{\circ} \mathrm{C}$, E.coli $\mathrm{O} 157: \mathrm{H} 7$ counts inoculated into Red Delicious apples increased by 2 - $3 \operatorname{logs}$ then remained constant thereafter for the 25 - day storage period. In McIntosh apples, there was an initial decrease in counts followed by an increase, but in this case freshly picked apples showed less increase as compared to apples that had been stored for one month following harvest. These results show that $E$. coli $\mathrm{O} 157: \mathrm{H} 7$ can survive in apple tissue for weeks following inoculation, and that the type of apple can affect survival and growth, as can the storage time following harvest.

Since our apples were bought from the store, we do not know their harvest date, but given that the U.S. grown Gala apples used in our study were bought in November and December, it is likely that they had been stored for 1-3 months following harvest (depending on the location of harvest).

Foley and others (2004) observed that irradiation at 1.05 kGy reduced E.coli O157:H7 by $6.7 \log$ in fresh cilantro, whereas a chlorine wash removed only 1.5 log cycles (Foley et al., 2004). These results highlight the efficacy of irradiation and also demonstrate the lack of sanitizer treatment efficacy in microbial reduction.

During storage over a period of 11 days, they also observed that E.coli O15:H7 counts did not change indicating that E.coli $\mathrm{O} 15: \mathrm{H} 7$ can survive storage under refrigerated conditions. In our study, $\mathrm{a} \approx 3 \log$ reduction can be obtained within the FDA limit of $1 \mathrm{kGy}$. However, this reduction is substantial compared to having no microbial reduction treatment for apples used for juicing. Also, if the contamination level of E.coli $\mathrm{O} 15: \mathrm{H} 7$ in apples is <3 log $\mathrm{CFU} / \mathrm{g}$, it is possible that the $1 \mathrm{kGy}$ treatment will be sufficient to eliminate the pathogen 
from the fruit.

Apple juice storage study: The survival of the outbreak strain of E.coli $\mathrm{O} 15: \mathrm{H} 7$ in apple juice was determined at $0 \mathrm{~h}, 24 \mathrm{~h}$ and $72 \mathrm{~h}$ storage following the 3-week storage period (Figure 3.1).

A

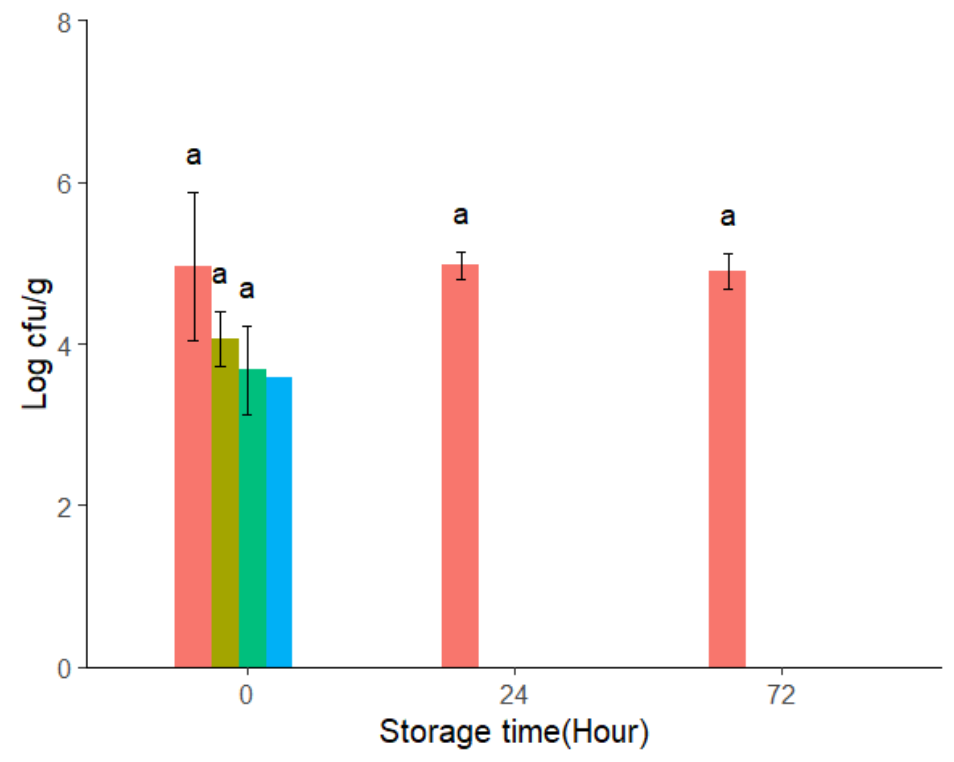

$\operatorname{Dose}(G y)$

000

234

423

615

819

B

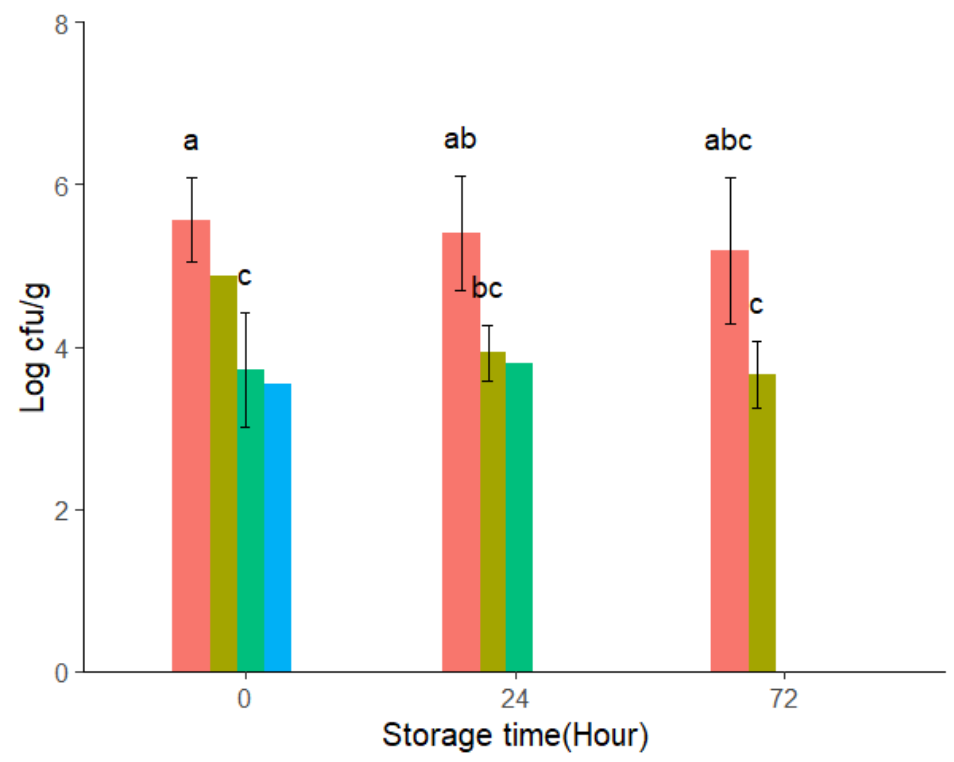

Dose(Gy)

000

188

390

606

789 
Figure 3.1: Survival of outbreak strain of E.coli $\mathrm{O} 15: \mathrm{H} 7$ in juice stored upto $72 \mathrm{~h}$ produced from irradiated apples kept in refrigerated storage for 3 weeks from Trial 1(A) and Trial 2(B). Different letters on top of each bar show significant differences $(\mathrm{p}<0.05)$ between treatment dose and storage time. **Bars in the graph without error bars have only one data point. No bars present for some data points since no survivors were obtained.

In the second trial, the counts in the control juice remained constant, similar to the first trial but after 24 and $72 \mathrm{~h}$ there were survivors in the juice of the apples irradiated at the low doses.

The survival of E.coli $\mathrm{O} 15: \mathrm{H} 7$ cells in irradiated commercial apple juice was studied by Hong and others (2014), where a $3.74 \log$ reduction was obtained after irradiation at $0.7 \mathrm{kGy}$. This is similar to our juice study where $\approx 3 \log$ reduction was observed for juice produced from $0.7 \mathrm{kGy}$ as seen in Figure 3.1, with no detectable survivors seen after $72 \mathrm{~h}$ of storage. This finding supports the premise that irradiation coupled with refrigerated storage can help achieve a significant pathogen reduction.

Hong and others (2014) also emphasized that due to radiation injury, sub lethally injured cells were able to grow on TSA, but were unable to form colonies on Sorbitol MacConkey Agar. Sub lethally injured cells can grow only on non-selective growth media since they undergo reversible damage of cell structures and functions (Schottroff et al., 2018). This could be the reason that, no survivors were observed at higher doses in the stored apples and juice.

The greater reduction in counts in the juice versus in the whole apples suggests that the E.coli $\mathrm{O} 15: \mathrm{H} 7$ cells within the punctures might have been protected from the free radicals generated in the aqueous media of the apples. When the apples were juiced, oxygenation of the juice may have increased the mortality of injured cells leading to the higher reduction of E.coli O15:H7 in the juice. Increased free radical reactions in the juice is another possibility, however it is unlikely that free radicals will have remained in the whole apples during the three-week storage.

Sensory analysis: Out of 55 panelists, 33\% could taste a difference between the control and treated apple juice, indicating that consumers could tell a difference between the irradiated and non-irradiated juice $(\mathrm{p}<0.05)$. The comments indicated that many panelists found the apple juice from the irradiated apples to be sweeter than juice from control apples. Control apples were 
perceived to be tarter.

Boynton and others (2006) found that cantaloupes irradiated at $1 \mathrm{kGy}$ had a significantly higher sweetness after storage at Day 11 and 20 than that of control cantaloupes. The authors suggested that the difference in sweetness might be attributed to lower glucose, fructose and sucrose consumption in the irradiated fruit as a result of lower respiration rates (Boynton et al., 2006).

Shahbaz and others (2014) analyzed the juice produced from pomegranates irradiated at 0.4 and $1.0 \mathrm{kGy}$. Although the total and reducing sugar content was the same for both doses, sensory analysis showed that the panelists preferred juice from the 0.4 and $1 \mathrm{kGy}$ irradiated pomegranates when compared to the juice from control and $2 \mathrm{kGy}$ irradiated pomegranates. The higher liking was attributed to greater sweetness of the pomegranates treated at 0.4 and $1.0 \mathrm{kGy}$.

\section{Conclusion}

E. coli $\mathrm{O} 157: \mathrm{H} 7$ showed greater attachment to apple flesh as compared to intact apple cuticle surface and survived for 3 weeks in untreated apples. Juicing resulted in a decrease in counts by one log, but no further reduction was seen during storage of the juice for three days which highlights the resilience of E. coli $\mathrm{O} 15: \mathrm{H} 7$ in this matrix. Irradiation of apples used for juicing at the FDA limit of $1 \mathrm{kGy}$ can achieve a 3-log reduction of E. coli O15:H7 and confer a significant margin of safety. Juicing of the irradiated apples further decreased E. coli O15:H7 counts and survival was only observed in the juice made from control and 188 Gy treated apples indicating that irradiation may have caused damage to the cells which inhibited their survival in the juice.

\section{Future Research}

The study can be repeated using acid adapted E.coli O157:H7 strains which have higher irradiation resistance and could lead to a higher D value determination. Also, the use of apples contaminated at the calyx region will more effectively showcase the effect of irradiation on internalized cells. Since the survival of E.coli O157:H7 in juice made from irradiated apples was lower than the survival in the apple following storage, the chemistry of the juice matrix and its impact on pathogen survival should be researched. 


\section{References:}

Barkai-Golan, R., Follett, P.A., 2017. Irradiation for Quality Improvement, Microbial Safety and Phytosanitation of Fresh Produce, Elsevier. Nikki Levy.

Beach, C., 2016. 7 sick with E. coli; cider mill's products, facility test negative [WWW Document]. Food Saf. News. URL https://www.foodsafetynews.com/2016/11/7sick-with-e-coli-cider-mills-products-facility-test-negative/\#.WcvNpGhSzIU (accessed 11.3.16).

Boynton, B.B., Welt, B.A., Sims, C., Balaban, M.O., Brecht, J.K., Marshall, M.R., 2006. Effects of Low-dose Electron Beam Irradiation on Respiration, Microbiology, Texture, Color, and Sensory Characteristics of Fresh-cut Cantaloupe Stored in Modified-atmosphere Packages. J. Food Sci. 71, S149-S155. https://doi.org/10.1111/j.1365-2621.2006.tb08918.x

Buchanan, R.L., Edelson, S.G., Miller, R.L., Sapers, G.M., 1999. Contamination of Intact Apples after Immersion in an Aqueous Environment Containing Escherichia coli O157:H7. J. Food Prot. 62, 444-450. https://doi.org/10.4315/0362-028x-62.5.444

Buchanan, R.L., Edelson, S.G., Snipes, K., Boyd, G., 1998. Inactivation of Escherichia coli O157:H7 in apple juice by irradiation. Appl. Environ. Microbiol. 64, 45334535 .

Burnett, S.L., Beuchat, L.R., 2001. Human pathogens associated with raw produce and unpasteurized juices, and difficulties in decontamination. J. Ind. Microbiol.

Biotechnol. 27, 104-110. https://doi.org/10.1038/sj.jim.7000199

Burnett, S.L., Chen, J., R Beuchat, L., 2000. Attachment of Escherichia coli O157:H7 to the surfaces and internal structures of apples as detected by confocal scanning laser microscopy. Appl. Environ. Microbiol. 66, 4679-4687.

CDC, 1996. Outbreak of Escherichia coli O157 :H7 Infections Associated with Drinking Unpasteurized Commercial Apple Juice- British Columbia , California , Colorado and Washington, October 1996 [WWW Document]. URL https://www.cdc.gov/mmwr/preview/mmwrhtml/00044358.htm

Chung, D., Cho, T.J., Rhee, M.S., 2018. Citrus fruit extracts with carvacrol and thymol eliminated 7-log acid-adapted Escherichia coli O157:H7, Salmonella typhimurium, and Listeria monocytogenes: A potential of effective natural antibacterial agents. Food Res. Int. 107, 578-588. https://doi.org/10.1016/j.foodres.2018.03.011

Dingman, D.W., 2000. Growth of Escherichia coli O157:H7 in bruised apple (Malus domestica) tissue as influenced by cultivar, date of harvest, and source. Appl. Environ. Microbiol. 66, 1077-1083. https://doi.org/10.1128/AEM.66.3.10771083.2000

Fan, X., Niemera, B.A., Mattheis, J.P., Zhuang, H., Olson, D.W., 2005. Quality of Freshcut Apple Slices as Affected by Low-dose Ionizing Radiation and Calcium Ascorbate Treatment. J. Food Sci. 70, 143-148.

Fatemi, P., Laborde, L.F., Patton, J., Sapers, G.M., Annous, B., Knabel, S.J., 2016. Influence of Punctures, Cuts, and Surface Morphologies of Golden Delicious Apples on Penetration and Growth of Escherichia coli O157:H7. J. Food Prot. 69, 267-275. https://doi.org/10.4315/0362-028x-69.2.267

FDA, 2019. Ionizing Radiation for the treatment of Food [WWW Document]. URL https://www.ecfr.gov/cgi-bin/text- 
idx?SID=c9b212d0ba92cf37273f8ecf1657093c\&mc=true\&node=se21.3.179_126\&r $\mathrm{gn}=\operatorname{div} 8$ (accessed 4.30.19).

FDA, 2018. Guidance for Industry: Questions and Answers on Juice HACCP Regulation [WWW Document]. https://doi.org/FDA-2013-S-0610

Ferens, W.A., Hovde, C.J., 2011. Escherichia coli O157:H7: Animal Reservoir and Sources of Human Infection. Foodborne Pathog. Dis. 8, 465-487.

Foley, D., Euper, M., Caporaso, F., Prakash, A., 2004. Irradiation and Chlorination Effectively Reduces Escherichia coli O157:H7 Inoculated on Cilantro (Coriandrum sativum) without Negatively Affecting Quality. J. Food Prot. 67, 2092-2098. https://doi.org/10.4315/0362-028x-67.10.2092

Hassan, A.N., Frank, J.F., 2004. Attachment of Escherichia coli O157:H7 grown in tryptic soy broth and nutrient broth to apple and lettuce surfaces as related to cell hydrophobicity, surface charge, and capsule production. Int. J. Food Microbiol. 96, 103-109. https://doi.org/10.1016/S0168-1605(03)00160-0

Hatab, S., Athanasio, R., Holley, R., Rodas-Gonzalez, A., Narvaez-Bravo, C., 2016. Survival and Reduction of Shiga Toxin-Producing Escherichia coli in a Fresh ColdPressed Juice Treated with Antimicrobial Plant Extracts. J. Food Sci. 81, M1987M1995. https://doi.org/10.1111/1750-3841.13382

Hong, S., Mendonça, A.F., Daraba, A., Shaw, A., 2014. Radiation Resistance and Injury in Starved Escherichia coli O157:H7 Treated with Electron-Beam Irradiation in 0.85\% Saline and in Apple Juice . Foodborne Pathog. Dis. 11, 900-906. https://doi.org/10.1089/fpd.2014.1782

Huang, Z., Hu, H., Shen, F., Wu, B., Wang, X., Zhang, B., Wang, W., Liu, L., Liu, J., Chen, C., Zhang, R., Chen, R., Wang, Y., Wu, T., Xu, X., Han, Z., Zhang, X., 2018. Relatively high acidity is an important breeding objective for fresh juice-specific apple cultivars. Sci. Hortic. (Amsterdam). 233, 29-37. https://doi.org/10.1016/j.scienta.2018.01.026

Jeong, S.G., Kang, D.H., 2017. Inactivation of Escherichia coli O157:H7, Salmonella Typhimurium, and Listeria monocytogenes in ready-to-bake cookie dough by gamma and electron beam irradiation. Food Microbiol. 64, 172-178. https://doi.org/10.1016/j.fm.2016.12.017

Jung, K., Go, S.-M., Moon, B.-G., Song, B.-S., Park, J.-H., 2016. Comparative Study on the Sensory Properties of Fuji Apples and Niitaka Pears Irradiated by Gamma Rays, Electron Beams, or X-rays. Food Sci. Technol. Res. 22, 23-29. https://doi.org/10.3136/fstr.22.23

Kahraman, O., Lee, H., Zhang, W., Feng, H., 2017. Manothermosonication (MTS) treatment of apple-carrot juice blend for inactivation of Escherichia coli 0157:H7. Ultrason. Sonochem. 38, 820-828. https://doi.org/10.1016/j.ultsonch.2016.11.024

Kilonzo Nthenge, A.K., 2012. Gamma Irradiation for Fresh Produce [WWW Document]. InTech.

Kong, Q., Wu, A., Qi, W., Qi, R., Carter, J.M., Rasooly, R., He, X., 2014. Effects of electron-beam irradiation on blueberries inoculated with Escherichia coli and their nutritional quality and shelf life. Postharvest Biol. Technol. 95, 28-35. https://doi.org/10.1016/j.postharvbio.2014.04.004

Mahmoud, B.S.M., Nannapaneni, R., Chang, S., Coker, R., 2016. Effect of X-ray treatments on Escherichia coli O157: H7, Listeria monocytogenes, Shigella flexneri, 
Salmonella enterica and inherent microbiota on whole mangoes. Lett. Appl.

Microbiol. 62, 138-144. https://doi.org/10.1111/lam.12518

Marler, B., 2013. Another Lesson Learned the Hard Way: Odwalla E.coli outbreak 1996

[WWW Document]. Marler Clark. URL https://www.marlerblog.com/legal-

cases/another-lesson-learned-the-hard-way-odwalla-e-coli-outbreak-1996/

Martinez-Gonzales, N.E., Castillo, A., 2016. Food Hygiene and Toxicology in Ready-toeat foods. Elsevier. https://doi.org/https://doi.org/10.1016/B978-0-12-8019160.00011-X

Mayton, H.M., Marcus, I.M., Walker, S.L., 2019. Escherichia coli O157:H7 and Salmonella Typhimurium adhesion to spinach leaf surfaces: Sensitivity to water chemistry and nutrient availability. Food Microbiol. 78, 134-142. https://doi.org/10.1016/j.fm.2018.10.002

Montibus, M., Ismaïl, R., Michel, V., Federighi, M., Aviat, F., Le Bayon, I., 2016. Assessment of Penicillium expansum and Escherichia coli transfer from poplar crates to apples. Food Control 60, 95-102. https://doi.org/10.1016/j.foodcont.2015.07.025

Moreira, R.G., Puerta-Gomez, A.F., Kim, J., Castell-Perez, M.E., 2012. Factors Affecting Radiation D-Values (D10) of an Escherichia Coli Cocktail and Salmonella Typhimurium LT2 Inoculated in Fresh Produce. J. Food Sci. 77. https://doi.org/10.1111/j.1750-3841.2011.02603.x

Moriarty, M.J., Semmens, K., Bissonnette, G.K., Jaczynski, J., 2019. Internalization assessment of E. coli O157:H7 in hydroponically grown lettuce. Lwt 100, 183-188. https://doi.org/10.1016/j.lwt.2018.10.060

Mostafavi, H.A., Mirmajlessi, S.M., Mirjalili, S.M., Fathollahi, H., Askari, H., 2012. Gamma radiation effects on physico-chemical parameters of apple fruit during commercial post-harvest preservation. Radiat. Phys. Chem. 81, 666-671. https://doi.org/10.1016/j.radphyschem.2012.02.015

Neal, J.A., Cabrera-Diaz, E., Marquez-Gonzalez, M., Maxim, J.E., Castillo, A., 2016. Reduction of Escherichia coli O157:H7 and Salmonella on Baby Spinach, Using Electron Beam Radiation. J. Food Prot. 71, 2415-2420. https://doi.org/10.4315/0362-028x-71.12.2415

Niemira, B.A., 2008. Irradiation compared with chlorination for elimination of Escherichia coli O157:H7 internalized in lettuce leaves: Influence of lettuce variety. J. Food Sci. 73. https://doi.org/10.1111/j.1750-3841.2008.00746.x

Niemira, B.A., Sommers, C.H., Fan, X., 2002. Suspending Lettuce Type Influences Recoverability and Radiation Sensitivity of Escherichia coli O157:H7. J. Food Prot. 65, 1388-1393. https://doi.org/10.4315/0362-028x-65.9.1388

R Core Team, 2017. R: A Language and Environment for Statistical Computing [WWW Document]. R Found. Stat. Comput. URL https://www.r-project.org/

Ryu, J.-H., Beuchat, L.R., 2005. Biofilm formation by Escherichia coli O157:H7 on stainless steel: effect of exopolysaccharide and Curli production on its resistance to chlorine. Appl. Environ. Microbiol. 71, 247-54. https://doi.org/10.1128/AEM.71.1.247-254.2005

Sapers, G.M., Miller, R.L., Mattrazzo, A.M., 1999. Effectiveness of sanitizing agents in inactivating Escherichia coli in golden delicious apples. J. Food Sci. 64, 734-737. https://doi.org/10.1111/j.1365-2621.1999.tb15121.x 
Schottroff, F., Fröhling, A., Zunabovic-Pichler, M., Krottenthaler, A., Schlüter, O., Jäger, H., 2018. Sublethal injury and Viable but Non-culturable (VBNC) state in microorganisms during preservation of food and biological materials by non-thermal processes. Front. Microbiol. 9, 1-19. https://doi.org/10.3389/fmicb.2018.02773

Shahbaz, H.M., Ahn, J.J., Akram, K., Kim, H.Y., Park, E.J., Kwon, J.H., 2014. Chemical and sensory quality of fresh pomegranate fruits exposed to gamma radiation as quarantine treatment. Food Chem. 145, 312-318. https://doi.org/10.1016/j.foodchem.2013.08.052

Stearns, D., 2015. A Decade History of E. coli Outbreaks Linked to Unpasteurized Apple Juice [WWW Document]. Food Poison J. URL https://www.foodpoisonjournal.com/foodborne-illness-outbreaks/a-history-of-e-colioutbreaks-linked-to-unpasteurized-apple-juice/ (accessed 10.24.15).

Stopforth, J.D., Ikeda, J.S., Kendall, P.A., Sofos, J.N., 2004. Survival of acid-adapted or nonadapted Escherichia coli O157:H7 in apple wounds and surrounding tissue following chemical treatments and storage. Int. J. Food Microbiol. 90, 51-61. https://doi.org/10.1016/S0168-1605(03)00171-5

Usaga, J., Worobo, R.W., Padilla-Zakour, O.I., 2014. Effect of Acid Adaptation and Acid Shock on Thermal Tolerance and Survival of Escherichia coli O157:H7 and O111 in Apple Juice. J. Food Prot. 77, 1656-1663. https://doi.org/10.4315/0362-028x.jfp-14126

VDACS, 2018. Mountain Man Market Recalls "Mountain Man Apple Cider" Because Of Possible Health Risk [WWW Document]. URL http://www.vdacs.virginia.gov/press-releases-181128-appleciderrecall.shtml (accessed 11.28.18).

Vojdani, J.D., Beuchat, L.R., Tauze, R. V., 2016. Juice-Associated Outbreaks of Human Illness in the United States, 1995 through 2005. J. Food Prot. 71, 356-364. https://doi.org/10.4315/0362-028x-71.2.356

Wisniewsky, M.A., Glatz, B.A., Gleason, M.L., Reitmeir, C.A., 2000. Reduction of Escherichia coli O157:H7 Counts on Whole Fresh Apples by Treatment with Sanitizers. J. Food Prot. 63, 703-708. https://doi.org/10.4315/0362-028x-63.6.703

Young Lee, N., Jo, C., Hwa Shin, D., Geun Kim, W., Woo Byun, M., 2006. Effect of $\gamma$ irradiation on pathogens inoculated into ready-to-use vegetables. Food Microbiol. 23, 649-656. https://doi.org/10.1016/j.fm.2005.12.001 